\title{
Analysis on Tourism Evaluation and Cooperative Mechanism of Liaoxi Corridor
}

\author{
Wang Hui* \\ Management College \\ Bohai University, Jinzhiu, China \\ E-mail: wswh7658@163.com
}

\author{
He Yue \\ Management College \\ Bohai University, Jinzhou, China \\ E-mail: hyno123@163.com
}

\begin{abstract}
As an important passageway between northeast and north China, Liaoxi corridor which is a culturally and ethnically diverse region with rich cultural relics and profound and long history connects northeast and southwest of China. Based on the review of local tourism and comprehensive evaluation of tourism, this paper puts forward the framework of cooperative strategy for the development of heritage tourism of Liaoxi corridor from the perspective of regional tourist cooperative development to facilitate the development of heritage tourism in Liaoxi corridor.
\end{abstract}

Keywords_Liaoxi corridor; tourism; cooperative development

\section{INTRODUCTION}

Regional economic integration and globalization objectively make various regional cooperation become the major channel to enhance regional competitiveness and thus affect the pattern of regional economy. Regional cooperation and development have become the theme of tourist economy. Regional resultant force has been formed by integrating resources, exchanging information and sharing market to improve overall tourist competitiveness [1]. At present, the competition among subjects of tourism in Liaoxi corridor region has become more and more intense, causing such problems as similar tourist service, repetitive construction projects and interest distribution issues among government, tourist companies and the grassroots level. Therefore, this paper puts forward the framework of cooperative strategy for the development of heritage tourism of Liaoxi corridor from the perspective of regional tourist cooperative development to facilitate the development of heritage tourism in Liaoxi corridor.

\section{REVIEW OF LOCAL TOURISM IN CORRIDOR}

In spatial distribution, located at the intersection of Inner Mongolia, Hebei and Liaoning, Liaoxi corridor is an indispensible part of the Belt and Road of northeast Asia and city group of Bohai bay, linking with cities of Shenyang to its east and cities of Beijing, Tianjin and Hebei to its west. In the broadest sense, it includes Huludao, Chaoyang, Fuxin, Panjin and Liaoxi of Jinzhou. Up to March 2017, in 251protecion sites of the 9th provincial cultural relics issued by Liaoning province, there are 76 sites in the corridor, accounting for $30.28 \%$ in the whole province, which indicates that the spatial combined

Fund Program: phased achievement jointly supported by Liaoning planning fund of social science (L17DGL002, L16BMZ001), Liaoning Educational Department project(WW2017001, WFW201704) and Shenyang planning project of special fund of philosophy and social science(17037) effect of heritage tourist resources is extremely marked in the corridor (as shown in Table 1). Xincheng city walls (city walls of Ming and Qing dynasties), Chaoyang Hongshan cultural relics (Niuheliang site) and Daxiong hall of Fengguo temple of Yi county of Jinzhou have been listed as tentative list of World Cultural Heritage of China. In 2017, the national new deal about cultural industry pointed out that Liaoxi corridor is one of the historical and cultural agglomerations in China with outstanding potential advantages in regional tourist competition, drawing tourists from Russia, South Korea and Japan of northeast, thus, it should actively promote the pilot project of cultural consumption.

TABLE I. TYPESOF TOURISM RESOURCES IN LIAOXI CORRIDOR

\begin{tabular}{|l|c|l|c|c|}
\hline & $\begin{array}{l}\text { World } \\
\text { Cultural } \\
\text { Heritage }\end{array}$ & $\begin{array}{l}\text { National } \\
\text { Park }\end{array}$ & $\begin{array}{l}\text { National } \\
\text { conservation } \\
\text { units }\end{array}$ & Total \\
\hline Huludao & 1 & 1 & 12 & 14 \\
\hline Chaoyang & 0 & 1 & 15 & 16 \\
\hline Fuxin & 0 & 0 & 5 & 5 \\
\hline Panjin & 0 & 0 & 1 & 1 \\
\hline Jinzhou & 0 & 1 & 9 & 10 \\
\hline Liaoxi corridor & 1 & 3 & 42 & 46 \\
\hline Liaoning province & 6 & 9 & 128 & 143 \\
\hline Proportion & 20 & 33.3 & 32.8 & 32.2 \\
\hline
\end{tabular}

a. Information source: processing related data from UNESCO World Heritage Centre and State Administration of Cultural Heritage.

\section{OVERALL EVALUATION OF TOURISM IN CORRIDOR}

\section{A. Tourist growth and its status}

Between 2012 and 2016, the average annual income of tourism in the corridor increased followed by decreased and then increased. The tourist income in the whole province and each city culminated in 2014 and decreased to the lowest. In general, the tourism income in the corridor showed an increase trend. Compared with average annual tourism income in the whole province, total tourism income of Liaoxi corridor accounts for about $1 / 5$ of Liaoning province.

In particular in 2015, the total income of tourism in the corridor accounted for 50\% and 65\% in Shenyang and Dalian respectively (in 2015, the total income of tourism in Shenyang and Dalian is 122.12 billion yuan and 100.87 billion yuan). The number of tourist cities in Liaoxi corridor is overwhelming but 
the combined effect is not given play to. The contribution to the tourism revenue of the province is still to be improved. It does not show its corresponding tourist status in Liaoning province (as shown in Table 2). Table 2 Tourist income of each city in Liaoxi corridor between 2012 and 2016 (unit: 100 million)

TABLE II. TOURISM INCOME OF LIAOXI CORRIDOR (UNIT: 100 MILLION)

\begin{tabular}{|l|c|c|c|c|c|}
\hline & $\mathbf{2 0 1 2}$ & $\mathbf{2 0 1 3}$ & $\mathbf{2 0 1 4}$ & $\mathbf{2 0 1 5}$ & $\mathbf{2 0 1 6}$ \\
\hline Huludao & 207.1 & 210 & 266.4 & 145 & 167 \\
\hline Chaoyang & 114.9 & 186.3 & 297.4 & 129.8 & 146.7 \\
\hline Fuxin & 56.6 & 68 & 77.2 & 69.2 & 78.3 \\
\hline Panjin & 145 & 254 & 211.3 & 168 & 194 \\
\hline Jinzhou & 172.7 & 235.7 & 272.2 & 153.1 & 174.7 \\
\hline Liaoxi corridor & 696.3 & 954 & 1124.5 & 665.1 & 760.7 \\
\hline Liaoning province & 3939 & 4648.1 & 5312.6 & 3722.7 & 4225 \\
\hline Proportion & 17.7 & 20.5 & 21.2 & 17.9 & 18 \\
\hline
\end{tabular}

${ }^{\text {b. }}$ Information source: processing data from national economy statistical bulletin of social development of each city in Liaoning province.

It shows from the increase of annual tourist income in the corridor that the increase of most cities in the corridor is close to or higher than the provincial average( about $14 \%$ in Liaoning province), which indicates that various cities in the corridor have an increased contribution to the development of tourism in the province (as shown in Figure 1). In 2015, after experiencing lowest income of tourism in each city in the corridor, the tourist income of Huludao, Chaoyang, Jinzhou and other cities realized significantly increase, which vigorously promote the recovery and revitalization provincial economy.

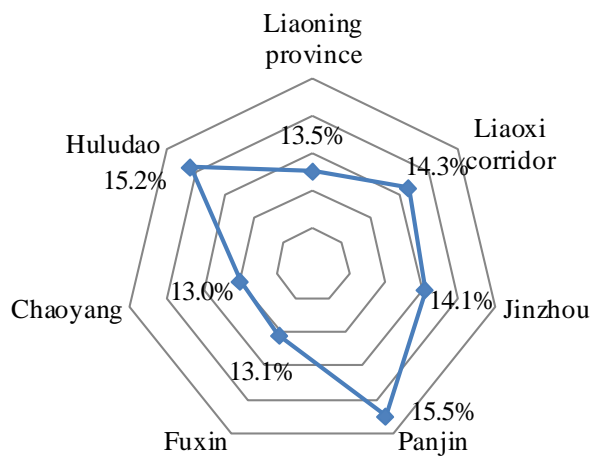

Fig. 1. Annual tourist increase rate between 2012 and 2016

\section{B. Tourist development and cooperation}

As the hub of cultural dispatch, Liaoxi corridor has rich heritage resources and steady growth for its tourism, but it is more about competition than cooperation for each city in the corridor. Such problems as similar tourist service, large number of tourist attractions but with low quality, disordered planning occur. It is still lack of ability for outside corridor to compete with other cities or regions and overall advantages cannot be made full use [2]. The contradictory between development and cooperation of tourism in the corridor stands out with each passing years. In the final analysis, it is the issue of interest distribution. On the basis of the investigation, the major task to solve the issue of the development and cooperation for the tourist activities based on cultural heritage is to reconcile the contradictory between the government, companies and residents inhabited in tourist destinations, thus building barrierfree tourism in the corridor.

\section{TOURISM COOPERATIVE MECHANISM IN LIAOXI CORRIDOR AND SUGGESTIONS}

\section{A. Reasonable planning of government-led tourist economic zone}

It should carry out government-led development strategy in its initial development if each city in Liaoxi corridor want to have new breakthrough in its tourism and build "shared community of heritage tourism in Liaoxi corridor" to develop its tourism [3]. Therefore, it should plan cultural heritage resource in a scientific way to guarantee the optimization of resources allocation, which is also the platform in the future, development for the corridor tourism. The government employs related experts and research institutions of tourism to jointly formulate the plans of regional tourist cooperation which ensures the feasibility and scientificity of tourist cooperation in the corridor. In the process of formulating tourist development plan, each city evaluates the conditions and foundation of tourist cooperation in the corridor in a scientific manner, clarifies the cooperative principles and objectives, especially for key cooperative projects and points out cooperative strategy and solutions. In addition, every city in the corridor should try to communicate with each other in their plans of tourist development to ensure that their plans can be carried out under the framework of overall economic development of Liaoxi corridor. In the future development, the plan should be characterized by long-term period, directivity, holistic view and authority. Meanwhile, trans-regional cooperative and coordinated mechanism should be built on the basis of planning and infrastructure should also be pushed forward in the corridor in a cooperative manner.

\section{B. Market-driven enterprise operation}

It should base on mature and perfect market economic system to conduct tourist cooperation in Liaoxi corridor, create open, orderly and fair market environment and build distinct market system in the corridor, which will lay a solid foundation for excellent tourist service and environment in the corridor and promote the overall development of tourist market in the corridor [4]. The conditions for tourist cooperation in Liaoxi corridor is relatively mature and the main transport in the corridor is highway and railway. "Beijing-Shenyang highspeed train will be built in the future which will inject new vitality to the development of Liaoxi and make the traffic network in the corridor more perfect. With the comprehensive influence of the open of high-speed train and existing railway line and rich cultural heritage resources in the corridor, the development potential is immeasurable. It should carry out tourist cooperation in the corridor as soon as possible, 
encourage related companies in the corridor to run extra passenger traffic lines to other regions (or neighboring provinces and cities) and strengthen the connection among each city in the corridor, thus forming the patter of "complementing each other as destinations and tourist generating areas", breaking through regional limitation and ultimately becoming a leisure zone for cultural heritage tourism in Liaoxi corridor.

The comprehensive feature of tourism makes it have stronger market economic characteristics. As those industries involving in tourism management, it should properly introduce market factor, encourage and promote private enterprises and capital to join in the development of cultural heritage tourism in the corridor and facilitate to reform the tourism-related system. In the initial development, if the companies are the operational subjects, then tourism in the corridor will develop into large-scale industry and bigger market.

\section{Optimizing investment environment and opening market}

The economic development in each city in Liaoxi corridor is unbalanced and falls behind compared with other cities of the province. But its tourist resource is relatively rich with high quality, thus there is large room to invest and cooperate for the tourism in the corridor. The foundation of tourist cooperation in Liaoxi corridor lies in the cooperation between industries and companies in each city. Taking the whole corridor into consideration, each government in the corridor can establish corresponding companies in accordance with their own resources, cooperate with various companies in a practical manner and actively cultivate sound market environment for tourist cooperation and development against the backdrop of intense competition in external tourist market, thus making each company in the corridor become the real operational subject in tourist cooperation. The reasons why tourist companies taking part in economic activities related with tourist cooperation in the corridor is that they need to develop and attach to the market to obtain the initiative. Meanwhile, corresponding preferential policies on tourist investment are provided for each tourist companies in the corridor to encourage and support them and individual to participate in the joint development of tourist commodities and resources. It can also attract foreign capital, social private capital or those supported by banks that are willing to make loans. In addition, those economically strong tourist companies and related economic entity in the corridor can adopt merger and acquisition to invest and jointly develop tourism or set up tourist companies to enjoy the same preferential policies in the corridor.

\section{Establishing and perfecting policy guarantee mechanism}

The establishment of tourist cooperative market is an inevitable choice for the development of tourism in the corridor. On the basis of tourist cooperative market, tourist activities in the corridor is the same as local tourism. The establishment of tourist cooperative market in the corridor requires regulating corresponding tourist policies in each city in order to avoid barriers and obstacles in the process of tourist cooperation and promote the prosperity and development of tourism in an all- round manner in the corridor. The premise for the mature of tourism in Liaoxi corridor is to possess a complete tourist policies and regulations, which also guarantee fair and orderly competition and development of tourism.

The tourist cooperation carried out in Liaoxi corridor is the trans-regional one (different cities in different provinces). Therefore, there are differences of tourist policies at local level. In order to break through administrative division for better developing tourist cooperation in the corridor, it is urgent to establish and perfect related regulations, rules and laws to match the development of tourism in the corridor, regulate tourist cooperative market, build open and fair market environment for tourist cooperation and prevent unfair development and malicious competition in each city in the corridor from happening. As for the policymaking, on the one hand, it should emphasize "cooperation", that is the cooperation among subjects of tourism, objects and medium and tourist cooperative market influenced by these three parties' interaction; on the other hand, it should emphasize 'function", which means that the purpose of policymaking is to regulate the policies of tourist cooperation and differences of overall policies among each city in the corridor, especially the related policies, regional policies and competition policies of tourism sector.

\section{E. Standardization and unification of tourism information platform}

At present, various sharing economy grows rapidly, with no exception for the development of tourism. What we share in tourism is tourist information. It should build integrated tourist information platform in which the contents focus on communication between government and companies, governmental information and market information and people in each city can exchange and communicate to share resources [5]. In addition, coordination mechanism for tourist cooperation should be established and at the same time include motivation, interaction and trust mechanisms into the corridor. In the coordinated scope of this mechanism, the implementation of tourist cooperation in the corridor can ensure to share tourist information in each city and reduce information asymmetry in an uttermost manner among destinations, thus enhancing the trust each other, which is conducive to optimize and allocate resources, highlight the role of coordination mechanism and obtain cooperative efficiency and economic benefit for the tourist cooperation in each city in the corridor.

\section{Conclusion And ENLightenment}

The main problems that baffle the tourism cooperation in the corridor are the uneven development and marked difference of tourism in various cities, which can be solved by virtue of creative thinking. It requires to set up all-round creative system for the tourist cooperation in various cities in the corridor, thus ensuring that tourist cooperation is more solid and the establishment of creative system covers the aspects of institution, concept, system and organization among which conceptual innovation is the most important and the foundation and premise of other three aspects. Taking the successful cases of tourist cooperation for reference and according to backward 
economy in the corridor, obstacles in the development of tourist cooperation can be removed by developing and forming the cooperative way of heritage tourism with the corridor characteristics to highlight long-term effect of coordination mechanism of tourist cooperation. For example, BeijingTianjian-Hebei tourist integration breaks the traffic bottleneck in the process of regional tourist cooperation and proposes to use high-speed railway network as the breakthrough point for regional industrial development.

\section{REFERENCES}

1] Wang Hui, Chen Guang, Wei Bin, Analysis on Heritage Inheritance and Tourist Utilization [J]. Journal of Bohai University (Philosophy \& Social Science Edition), 2017, 39(03):63-66+82.

[2] Weibin, Wang Hui, Study on Development Strategy of Tourist Integration in Liaoxi Corridor [J].Decision-Making \& Consultancy, 2016(06):44-47.

[3] Yin Ping, Gao Xinna, On Beijing-Tianjin-Hebei Integration under the Influence of High-Speed Train [J]. People's Tribune, 2016(15):66-67.

[4] Guo Shu, A Study of Package Tour Market Decrease From a Perspective of Tourism Supply Chain [J]. Journal of Liaoning University (Philosophy and Social Sciences Edition), 2015, 43(05):130-136.

[5] Zhou Li, Jiang Jinliang, Comprehensive Evaluation of Urban Touris m Competitiveness in the Yangtze River Delta and Its Spatial Patterns Analysis [J]. Economic Geography, 2015, 35(01):173-179.

[6] Zhu Hongbin, Feng Xiang, Research on Classification and Evaluation of Regional Tourism Cooperation Model in Yangtze River Delta [J]. Geography and Geo-Information Science, 2014, 30(03):108-113. 